\title{
Resource Recovery from Waste, Water and Wastewaters with Membrane Technologies
}

\author{
Ismail Koyuncu \\ koyuncu@itu.edu.tr \\ National Research Center on Membrane Technologies, Istanbul Technical University, Maslak, 34469 , \\ Istanbul, Turkey \\ Environmental Engineering Department, Istanbul Technical University, Maslak, 34469, Istanbul, Turkey
}

\section{Bihter Zeytuncu}

bihtzeytuncu@itu.edu.tr

National Research Center on Membrane Technologies, Istanbul Technical University, Maslak, 34469, Istanbul, Turkey

Environmental Engineering Department, Istanbul Technical University, Maslak, 34469, Istanbul, Turkey

\section{Mehmet Emin Pasaoglu}

mpasaoglu@itu.edu.tr

National Research Center on Membrane Technologies, Istanbul Technical University, Maslak, 34469, Istanbul, Turkey

Environmental Engineering Department, Istanbul Technical University, Maslak, 34469, Istanbul, Turkey

\section{Ayse Yuksekdag}

yuksekdaga@itu.edu.tr

National Research Center on Membrane Technologies, Istanbul Technical University, Maslak, 34469, Istanbul, Turkey

Environmental Engineering Department, Istanbul Technical University, Maslak, 34469, Istanbul, Turkey

\author{
Borte Kose-Mutlu \\ kosebo@itu.edu.tr \\ National Research Center on Membrane Technologies, Istanbul Technical University, Maslak, 34469, \\ Istanbul, Turkey \\ Civil Engineering Department, Yeditepe University, Istanbul, Turkey
}

\begin{abstract}
In this study, critical elements (Boron (B) and Rare Earth Elements (REE)) recovery is studied with membrane technologies. Concentrated boron can be recovered by using different technologies. Membrane technologies such as reverse osmosis have a potential to concentrate the boron. $\mathrm{pH}$ of the solution is very important if reverse osmosis is applied. Removal of boron at $\mathrm{pH}$ levels of 7 and 10 increases from $80 \%$ to $97 \%$ with reverse osmosis membranes. Another critical element is rare earth elements in the World. Rare earth elements (REE) is a group of elements that involve lanthanides, scandium and yttrium. A successful REE transport for wastewater was observed compared with the concentrate flow of the acidic waste slime.
\end{abstract}

Keywords: Shoring system; Contiguous pile wall; Cantilever retaining wall; Qatar

\section{INTRODUCTION}

Nowadays, wastewater treatment plants have started to be considered as resource recovery facilities. Expectations from resource recovery facilities are water reuse, chemical recovery (such as phosphorus, nitrogen etc.), energy recovery and critical elements recovery (boron, rare earth elements, etc.)

In areas where water scarcity is important in the world, the reuse of water is becoming more and more important. Practice of recovering nutrients ( $\mathrm{N}$ and $\mathrm{P})$ from wastewater 
and converting them into an environmental friendly fertilizer is also getting very important. Nutrient recovery provides a self-sustainable solution to WWTPs and helps to meet discharge limits. $\mathrm{PO} 3$ precipitation from wastewater is less energy intensive and economical (Theregowda et al., 2018). Energy positive wastewater treatment plants are also getting very important for sustainable wastewater management.

Critical elements are getting more and more vital with the increased requirement of these elements and the development of advanced technologies. There are $27 \mathrm{critical}$ elements according to European Union science hub raw materials information system (EU CRM list, 2017). Boron and REE are listed as possible critical raw materials for important industries by the European Union and the United States. In addition to this, some REEs were mentioned as "critical REEs". The supply of these elements, especially is limited.

Turkey is ranked top with its share of almost $73 \%$ in the global boron reserve standing in the world. There are four main boron production facilities in Turkey (Etimaden, 2019). High boron containing groundwater negatively affects agriculture due to the irrigation in a near basin. Boron concentration is changing around 50-150 $\mathrm{mg} / \mathrm{l}$ in geothermal water and 3000-6000 mg/l in groundwater. Removal of boron can be provided by several technologies such as adsorption, coagulation, ion-exchange, electrocoagulation and membranes processes such as electrodialysis, Reverse Osmosis (RO) and Membrane Distillation (MD). Concentrated boron can also be recovered by using different technologies.

Rare Earth Elements (REE) is a group of elements involving lanthanides, scandium and yttrium. REEs have various important uses and applications, which make REEs more essential. REEs are needed for a wide variety of products such as catalysts, hybrid vehicles, batteries, mobile phones, plasma televisions, disk drives, catalytic converters and fluorescent lamps. The industrial application demand for rare earth metals is increasing in the world.

The aim of this study is to execute the boron and REE potential of waste and wastewater and recover of these chemicals by advanced membrane separation techniques.

\section{MATERIALS AND METHODS}

High boron containing spring waters were collected from area of the Eti Maden Boron manufacturing facility in Emet-Kutahya, Turkey. In the experiments to adjust $\mathrm{pH}$ of water, high purity sodium hydroxide was used. Brackish Water (BW) and Seawater (SW) RO membranes were used in this study. RO membranes systems were performed as single and double stages with different combinations. The feed solution was first passed through UF and NF membrane to reject the colloidal materials and suspended solids as seen in Figure 1. After that two stages, RO membranes were obtained in the pilot scale system (Zeytuncu et al., 2019). 


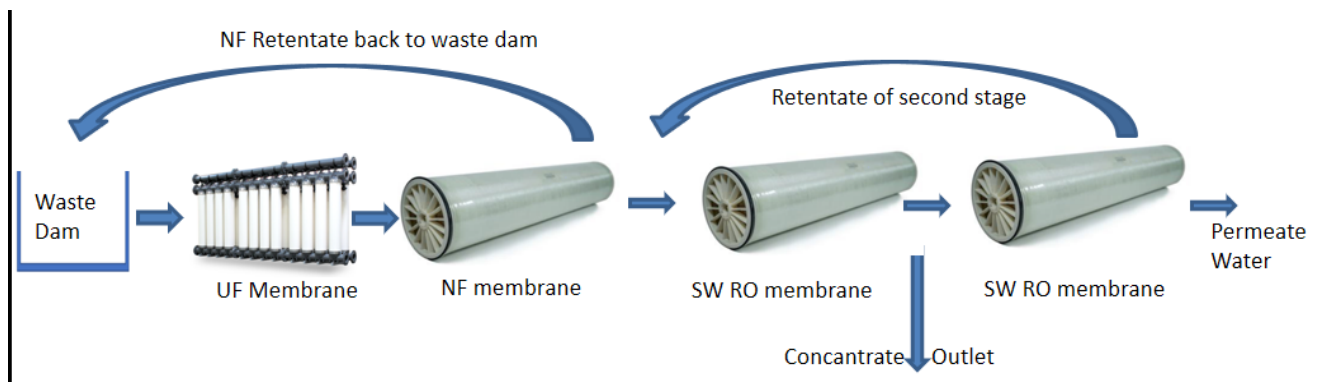

Figure 1: Flow chart of RO membrane system for boron removal from spring water

Boron concentration was analyzed by an inductively coupled plasma optical emission spectrometer (ICP-OES, Perkin Elmer). Other parameters such as $\mathrm{pH}$ and temperature were measured by portable meters. The percentage removal of boron is defined as per following equation:

$$
\text { Removal }=\left(1-\mathrm{C}_{\mathrm{p}} / \mathrm{C}_{\mathrm{f}}\right) \times 100 \%
$$

where $C_{f}$ and $C_{p}$ are the component concentration in the feed and permeate, respectively.

Wastewater and waste slime of the boron deposit site of Turkey were investigated for the recovery of REEs. A microwave digestion system (Berghof, Germany) was preferred for the preparation of acidic leach solution for the waste slime under $210{ }^{\circ} \mathrm{C}$ temperature for $30 \mathrm{~min}$. Both wastewater and waste acidic leach solutions were analyzed by using inductively coupled plasma (ICP, Perkin-Elmer, USA) to determine the major, trace and REE contents of samples. An X-ray fluorescence (XRF) (Bruker S8 Tiger, USA) analysis was carried out for waste slime, additionally. Two different membrane systems were combined to recover the REEs. First, a NF process was used to concentrate the leach solution of waste slime. On the other hand, the wastewater was concentrated by a pilot-scale cross-flow NF system in the mining plant. The concentrate flows of each NF process were fed to the SLM system as the second step of the recovery process which consists of an H-type microbial fuel cell reactor. Di-2-Ethylhexyl phosphoric acid (D2EHPA, 97\% purity) dissolved in kerosene $(10 \% \mathrm{v} / \mathrm{v})$ was used as an organic phase while $5 \mathrm{M} \mathrm{HNO}_{3}$ was used for the stripping of REEs. Samples were taken from each phase at $\mathrm{t}=0$ and $\mathrm{t}=3 \mathrm{~h}$ for the determination of REE and major element concentrations. Distribution coefficients of each REE were calculated according to the following equation (Yuksekdag et al., 2019).

$$
\mathrm{D}=[\mathrm{Me}]_{\text {strippant }} /[\mathrm{Me}]_{\text {feed }}
$$

\section{RESULTS AND DISCUSSIONS}

\subsection{Boron removal and recovery}

In this study, first single stage BWRO and SWRO processes were applied to remove boron from spring water containing approximately $3000 \mathrm{ppm}$ of boron concentration at $\mathrm{pH}$ 7. After this study, 2 pass processes (SWRO/SWRO, BWRO/SWRO, SWRO/ 
BWRO and BWRO/BWRO membrane systems) were examined at $\mathrm{pH}$ of 7 and 10 . The results of boron removal are given in Table 1 . The boron removal by single stage process is not good enough to meet irrigation criteria. At single stage BWRO the maximum boron removal was found to be as $58 \%$ at $\mathrm{pH}$ of 7 while $88 \%$ of boron removal was achieved for single stage SWRO membrane. Although the removal efficiency is around $88 \%$ with SWRO, problems such as clogging of membranes and low performance were encountered due to the hardness of the water. However, since it was seen that one stage would not be sufficient, so, two-stage studies were performed. When double stage RO membrane combinations were investigated one by one, it was seen that the most efficient result for boron removal was obtained by double SWRO membrane. Boron removal rates for double pass of SWRO membranes were given in Table 1. While first stage $\mathrm{pH}$ is 7 here, second stage $\mathrm{pH}$ is around 10. In SWRO/SWRO membrane system, the boron removal was gained $98.3 \%$ which was the most efficient result. It can be said by these results, that double pass SWRO is essential to meet the required criteria. Figure 2 shows the effect of $\mathrm{pH}$ on the boron removal in double pass $\mathrm{RO}$ membrane system. It is obvious that $\mathrm{pH}$ has an important role to play in boron removal performance. Boron removal increased from $80 \%$ at $\mathrm{pH} 7$ to more than $97 \%$ at $\mathrm{pH} 10$ owing to the increasing amount of borate ions while rising the $\mathrm{pH}$. More than $98 \%$ of boron removal can be achieved at a $\mathrm{pH}$ level of 11. Removal efficiency is increased especially after $\mathrm{pH}=9$ (Zeytuncu et al., 2019).

Table 1: Boron removal results in double stage RO configuration (Zeytuncu et al., 2019)

\begin{tabular}{|c|c|c|c|c|c|}
\hline & \multicolumn{2}{|c|}{ 1. Stage } & & \multicolumn{2}{|c|}{ 2. Stage } \\
\cline { 2 - 3 } \cline { 5 - 6 } & $\mathbf{p H}$ & $\begin{array}{c}\text { Boron removal, } \\
\%\end{array}$ & & $\mathbf{p H}$ & $\begin{array}{c}\text { Boron removal, } \\
\%\end{array}$ \\
\hline Single BWRO & 7.05 & 58.0 & - & - & - \\
\hline Single SWRO & 7.05 & 88.0 & - & - & - \\
\hline First Stage SWRO & 7.05 & 80.0 & Second Stage SWRO & 10.55 & 98.3 \\
\hline First Stage BWRO & 7.05 & 83.0 & Second Stage SWRO & 10.55 & 97.7 \\
\hline First Stage SWRO & 7.05 & 82.0 & Second Stage BWRO & 10.55 & 96.5 \\
\hline First Stage BWRO & 7.05 & 82.0 & Second Stage BWRO & 10.55 & 93.3 \\
\hline
\end{tabular}

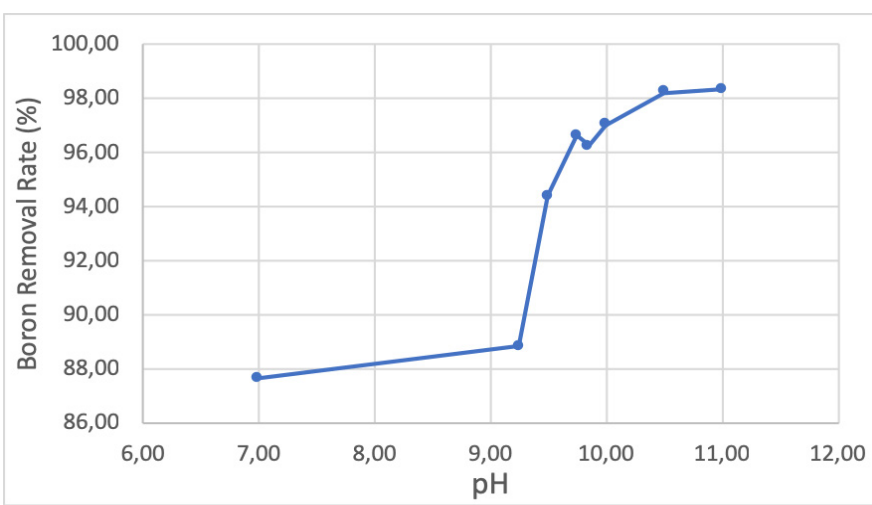

Figure 2: Boron removal for double pass RO membrane systems (Zeytuncu et al., 2019) 


\subsection{Rare earth elements recovery from wastes}

According to the results obtained from three different digestion methods, the highest total REE concentration was achieved by using $6 \mathrm{~mL} \mathrm{HNO} 3+1 \mathrm{~mL}$ HF acid mixture which was around $22 \mathrm{ppm}(\mathrm{wt} / \mathrm{wt}$ ) for the REE recovery studies (Figure 3). Individual concentrations of the top four elements for waste slime are $\mathrm{Ce}, \mathrm{La}, \mathrm{Y}$, and $\mathrm{Nd}$ respectively. On the other hand, Y concentration of wastewater was $25 \mathrm{ppb}$ in 27 $\mathrm{ppb}(\mathrm{wt} / \mathrm{v}$ ) total REEs. At the end of the NF process, a 70\% rejection and $40 \%$ REEs concentration ratio was obtained. As a result of the SLM process, it was confirmed that the distribution coefficients of rare earth elements for wastewater were higher than the acidic leach solution.

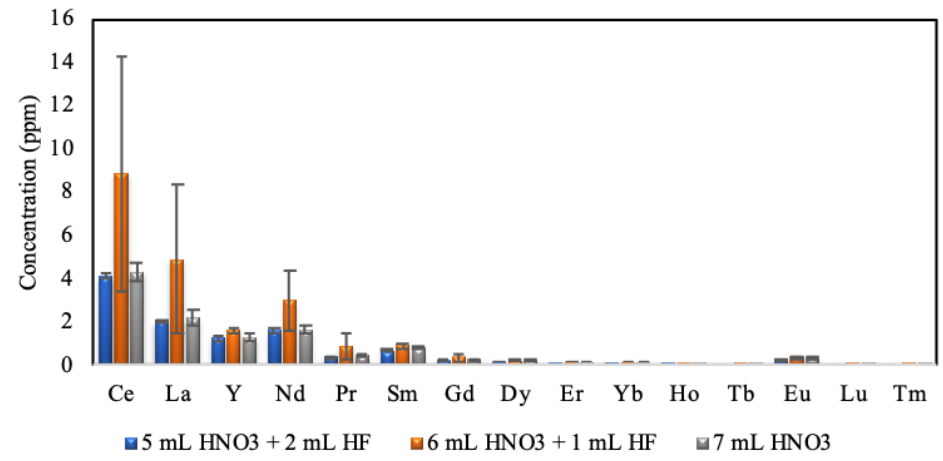

Figure 3: REE concentrations of waste slime (wt/wt)

\section{CONCLUSION}

It is obvious that $\mathrm{pH}$ has an important role to play in boron removal performance. Boron removal increased from $80 \%$ at $\mathrm{pH} 7$ to more than $97 \%$ at $\mathrm{pH} 10$ owing to the increasing amount of borate ions while rising the $\mathrm{pH}$. Concentrate stream can be further concentrated with evaporation-crystallation process and boric acid can be recovered from the final concentrate. It has a big economic value.

Rare earth element potential of waste and wastewater of boron mining plant were detected in Turkey. The top four elements with the highest concentration are $\mathrm{Ce}, \mathrm{La}$, $\mathrm{Y}$, and Nd respectively. A more successful REE transport for wastewater was observed compared with the concentrate flow of the acidic waste slime. It shows that wastewater of the boron deposit site should be considered as a secondary source for the recovery of REEs.

\section{ACKNOWLEDGMENTS}

This study was financially supported by The Scientific and Technological Research Council of Turkey (TUBITAK) (Project no:117Y357), Istanbul Technical University (ITU) Scientific Research Project (Project ID: 41893) and Eti Mining Operations General Directorate. The authors would also like to thank Geochemistry Research Laboratory for $\mathrm{XRF}$ analysis. 


\section{REFERENCES}

Etimaden (2019). Boron as the Rising Value of Turkey. Etimaden Publications, Turkey.

EU CRM List (2017). Study on the review of the list of the critical raw materials - Final Report by British Geological Survey, Bureau de Recherches Géologiques et Minières, Deloitte Sustainability, Directorate-General for Internal Market, Industry, Entrepreneurship and SMEs (European Commission), TNO. EU Publications.

Theregowda, R. B., Gonzalez-Mejia, M., Garland, J. \& Ma, X. (2018). Nutrient recovery from municipal wastewater for sustainable food production systems: An alternative to traditional fertilizers, AWWA Sustainable Water Management Conference.

Yuksekdag, A., Kose-Mutlu, B., Wiesner, M. R. \& Koyuncu, I. (2019). Toward Resource Recovery from Wastewater: Rare Earth Element Potentials and Membrane Technology for the Separation, International Water Association (IWA) Membrane Technology Conference \& Exhibition for Water and Wastewater Treatment and Reuse (IWA-MTC 2019). Toulouse, France.

Zeytuncu, B., Güçlü, S., Eryıldız, B., Yüksekdağ, A., Korkut, S., Türken, T., Paşaoğlu, M. E., Kaya, R., Kazak, A., Ceylan, M., Ünlü, Mİ., Ün, S., Yılmaz, S., Çeliker, A. \& Koyuncu, İ. (2019). Boron Removal from High Boron Containing Water Sources by Membrane Technologies. International Symposium on Boron - BORON 2019, Nevşehir, Turkey. 